\title{
The Effect of Fused Silica Crystallization on Flexural Strength and Shrinkage of Ceramic Cores for Investment Casting
}

\author{
Young-Hwan Kim****, Jeong-Gu Yeo*, , and Sung-Churl Choi*** \\ *Advanced Materials and Devices Laboratory, Korea Institute of Energy Research, Daejeon 34129, Korea \\ **Division of Materials Science and Engineering, Hanyang University, Seoul 04763, Korea \\ (Received January 5, 2016; Revised February 24, 2016; Accepted March 2, 2016)
}

\begin{abstract}
Complex designed silica-based ceramic cores were fabricated by ceramic injection molding. Slow heating rate $(0.2 \mathrm{~K} / \mathrm{min})$ for debinding restrained bloating on the surface of ceramic cores. To investigate effect of sintering conditions on mechanical properties of ceramic cores, green bodies were sintered at temperatures in a range from $1150^{\circ} \mathrm{C}$ to $1400^{\circ} \mathrm{C}$ for various dwelling times $(6$ $\mathrm{h}$ to $48 \mathrm{~h}$ ). Sintering above $1300^{\circ} \mathrm{C}$ for $12 \mathrm{~h}$ and dwelling time over $24 \mathrm{~h}$ at $1200^{\circ} \mathrm{C}$ reduce the flexural strength and increase the linear shrinkage of ceramic cores. Cristobalite, formed by high sintering temperature or long dwelling time, induces reduction of mechanical properties due to its phase transformation, which is accompanied by volume contraction and microcracking. Ceramic core sintered at $1200^{\circ} \mathrm{C}$ for $12 \mathrm{~h}$ endured wax patterning and shell molding, and was manufactured successfully.
\end{abstract}

Key words : Fused silica, Ceramic core, Mechanical properties, Crystallization

\section{Introduction}

$\mathbf{P}$ arts such as blades or vanes which are used in the gas turbines for power generation are generally made using Ni-based superalloy. Because it has to be used at high temperature for a long duration, it has a hollow structure in which complicated cooling path is formed. ${ }^{1)}$ High temperature parts with hollow structures are generally made by using a vacuum investment casting method with ceramic core and shell mold to form a cooling path having complicated shape. After casting using superalloy with ceramic core, remaining ceramic core inside solidified parts is chemically leached out by corrosive solution such as sodium hydroxide or potassium hydroxide inside autoclave, and finally hollow gas turbine parts are produced. ${ }^{2)}$

Ceramic core should have fracture strength enough not to be broken during wax patterning, shell molding, and investment casting of superalloys. Further, it should have a dimensional stability for forming cooling path having an accurate size. ${ }^{3-5)}$ Generally, since dimensional changes in fused silica are not big at high temperature during investment casting due to a low thermal expansion coefficient of $0.5 \times 10^{-6} / \mathrm{K}$, it is widely used as a primary material for making ceramic core. ${ }^{6)}$ A little amount of zircon is used as an additive for the core. ${ }^{7)}$ However, technology to manufac-

\footnotetext{
${ }^{\dagger}$ Corresponding author: Jeong-gu Yeo

E-mail : jgyeo@kier.re.kr

Tel : +82-42-860-3744 Fax : +82-42-860-3133

tCorresponding author: Sung-Churl Choi

E-mail : choi0505@hanyang.ac.kr

Tel : +82-2-2220-0505 Fax : +82-2-2291-6767
}

ture ceramic core is a know-how for manufacturers, that is why its composition or forming/sintering method are rarely disclosed. ${ }^{8)}$

Ceramic injection molding is a forming method which is the most generally used to manufacture ceramic core for vacuum investment casting. ${ }^{9)}$ Injected part goes through debinding before sintering. At this time, defects such as bloating of surface or distortion can be occurred. ${ }^{10)}$ Therefore, defects after heat treatment need to be restricted by adequate debinding temperature and heating rate. Besides, in the fused silica which is a matrix material of ceramic core, crystallization to cristobalite at temperature higher than $1300^{\circ} \mathrm{C}$ may occur. Further, phase transformation from $\beta$-phase to $\alpha$-phase cristobalite is proceeded during cooling. Due to volume contraction occurred at this time, micro-crack is generated. ${ }^{7}$ Therefore, adequate sintering temperature and time are required, enabling sufficient sintering while restricting crystallization of fused silica in order to manufacture ceramic core having an appropriate strength and low shrinkage rate.

In this study, ceramic core based on the silica for hot parts in the gas turbines was formed through an injection process, and physical properties changes by debinding and sintering condition were observed. Further, it was intended to establish an optimum condition for manufacturing ceramic core by reducing defects on the surface of ceramic core through thermal debinding step and by improving fracture strength by controlling sintering condition, and finally the obtained core withstands forces encountered during the mold making such as the wax patterning and shell molding of the vacuum investment casting of superalloys. 


\section{Experimental Procedure}

Fused silica and zircon powders were used at a ratio of $3: 1$ as a mixture that composes ceramic core. Fused silica with various sizes were used to increase flow-ability and particle packing density of feedstock for injection molding of ceramic core. Particle sizes of used fused silica and zircon powder are shown in Table 1. Paraffin wax (Nippon-Seiro, Japan) and microcrystalline wax (Nippon-Seiro, Japan) were used as thermoplastic binders, while stearic acid $\left(\mathrm{C}_{19} \mathrm{H}_{36} \mathrm{O}_{2}\right.$, Samchun Pure Chemical, Korea) and oleic acid $\left(\mathrm{C}_{19} \mathrm{H}_{34} \mathrm{O}_{2}\right.$, Samchun Pure Chemical, Korea) were used as lubricants. Amount of ceramic powder inside feedstock was set at $85 \mathrm{wt} \%$.

Ceramic powder was ball milled at room temperature for six hours using zirconia ball having a diameter of $6 \mathrm{~mm}$ to mix powder uniformly. Ceramic powder was mixed with thermoplastic binder which was melt at $80^{\circ} \mathrm{C}$ for $6 \mathrm{~h}$ using a planetary vacuum mixer. Prepared feedstock was input into a mixing tank in the ceramic injection molding machine (CTM-CI-CF-35ton, Cleveland, United States) and stirred at $80^{\circ} \mathrm{C}$ for $3 \mathrm{~h}$. Ceramic core was injected and formed under the injection molding condition as described in Table 2. Ceramic core prepared in this study is for second blade of GT11NM model for gas turbine from the Alstom, and a specimen having rectangular shape with size $6 \times 8 \times 90 \mathrm{~mm}$ (ASTM C1161-13 ${ }^{11)}$ ) was formed by injection molding to measure physical properties of the specimen. Injected ceramic core was heat-treated while it was positioned inside of backfill powder of fused silica to prevent collapse of injected part of thermoplastic binder while debinding. Debinding and sintering were sequentially processed for heat treatment of the ceramic core. Temperature was raised with speed at $0.2 \sim 5.0 \mathrm{~K} / \mathrm{min}$ until $300^{\circ} \mathrm{C}$ for debinding of

Table 1. Characteristics of the Raw Powders for Silica-Based Ceramic Cores

\begin{tabular}{cccc}
\hline Materials & $\mathrm{D}_{50}(\mu \mathrm{m})$ & Purity (\%) & Company \\
\hline Fused silica & 283 & 99.6 & Boram Chemetal (Korea) \\
Fused silica & 81 & 99.6 & Boram Chemetal (Korea) \\
Fused silica & 20 & 99.6 & Boram Chemetal (Korea) \\
Fused silica & 12 & 99.6 & Boram Chemetal (Korea) \\
Fused silica & 2.098 & 99.7 & Sibelco (Belgium) \\
Fused silica & 0.523 & 99.8 & Denka (Japan) \\
Zircon flour & 2.223 & 97.5 & Cenotec (Korea) \\
\hline
\end{tabular}

Table 2. Conditions for Injection Molding of Ceramic Cores

\begin{tabular}{cc}
\hline Conditions & Value \\
\hline Injection temp. & $75^{\circ} \mathrm{C}$ \\
Injection time & 30 second \\
Injection pressure & $60 \mathrm{bar}$ \\
Clamping force & $21 \mathrm{ton}$ \\
Flow rate & $200 \mathrm{cc} / \mathrm{sec}$ \\
\hline
\end{tabular}

thermoplastic binder in order to investigate effects of heating rate on the appearance of ceramic core. After debinding process, the ceramic core was heat-treated at sintering temperature $1150 \sim 1400^{\circ} \mathrm{C}$ for a sintering time $6 \sim 48 \mathrm{~h}$. Heattreated specimen was wax patterned using a wax injection molding machine (MPI, United States). After wax patterning, a shell mold was prepared and sintered at higher than $1000^{\circ} \mathrm{C}$.

Flexural strength of the heat-treated specimen was measured with crosshead speed at $1 \mathrm{~mm} / \mathrm{min}$ in $80 \mathrm{~mm}$ span size using universal testing machine (UTM, H10SK, Hounsfield, England). Further, lengths of the specimens were measured before and after heat treatment to check linear shrinkage of the specimens. After sintering, microstructure of the ceramic core was observed using field emission scanning electron microscopy (FE-SEM, S-4700 and S-4800, Hitachi, Japan). Besides, phase transformation of material was observed using X-Ray diffractometer (XRD, D/Max2200, Rigaku, Japan). And then, X-ray inspection was carried out in order to check defects and fracture of ceramic core after wax patterning and shell-molding.

\section{Results and Discussion}

\subsection{Debinding of injected ceramic core}

Thermogravimetric analysis and differential thermal analysis (TG/DTA) were carried out to select debinding condition for the specimen formed by ceramic injection molding, and the results are presented in Fig. 1. Analysis results showed that weight of thermoplastic binder started reducing at near $200^{\circ} \mathrm{C}$, and almost of the thermoplastic binder was evaporated at near $300^{\circ} \mathrm{C}$. Therefore, appearance changes of injection molding part by debinding before sintering was observed at debinding temperature $300^{\circ} \mathrm{C}$.

Images of appearance and fracture area of specimen, after sintering according to heating rate till debinding temperature, are shown in Fig. 2. Each specimen was exposed to temperature until $300^{\circ} \mathrm{C}$ with different heating rate, was maintained for $1 \mathrm{~h}$, and then heat-treated at $1200^{\circ} \mathrm{C}$ for $12 \mathrm{~h}$. In

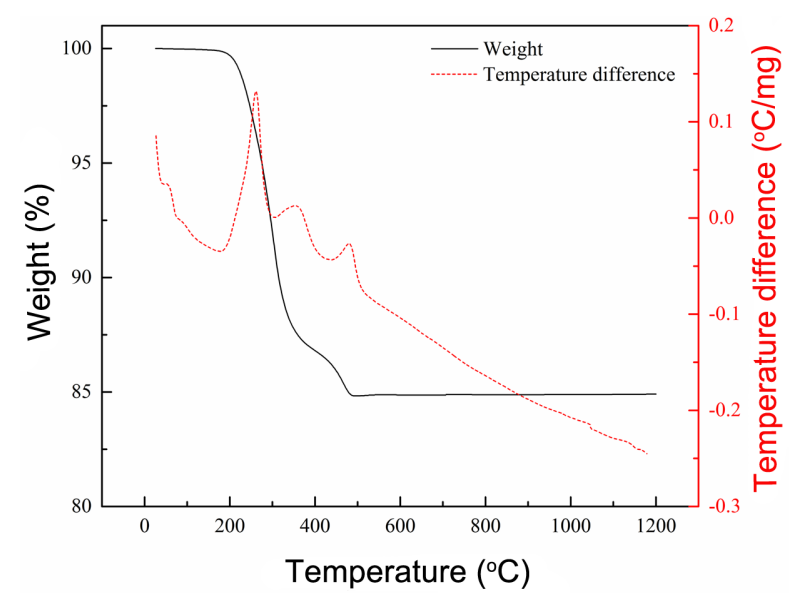

Fig. 1. TG/DTA graph of injected green part. 


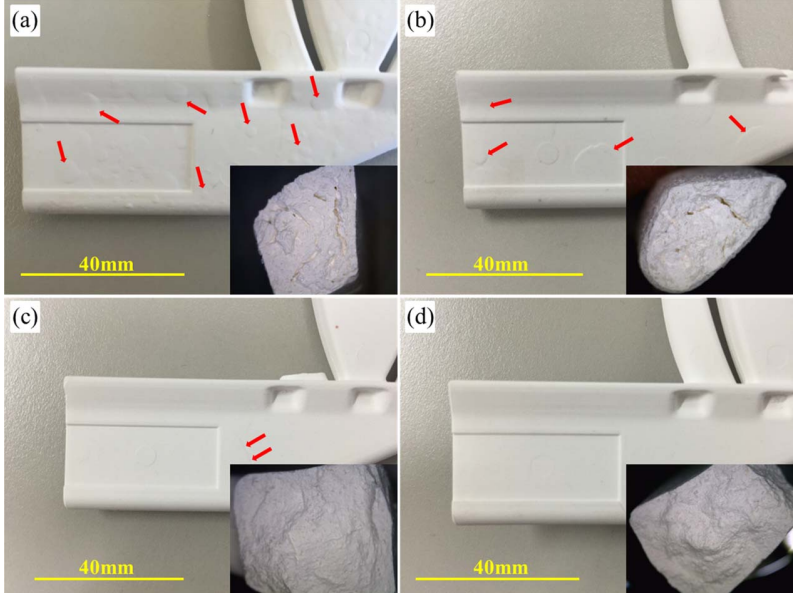

Fig. 2. Surface and cross section images of specimens with various heating rate for debinding $\left(300^{\circ} \mathrm{C}\right)$; (a) $5.0 \mathrm{~K} / \mathrm{min}$, (b) $1.0 \mathrm{~K} / \mathrm{min}$, (c) $0.5 \mathrm{~K} / \mathrm{min}$, and (d) $0.2 \mathrm{~K} / \mathrm{min}$

case injected part was heated abruptly till debinding temperature, blister which is a phenomenon of expansion in the surface was generated after heat treatment. Particularly, when temperature was increased till debinding temperature with speed at $5.0 \mathrm{~K} / \mathrm{min}$ and $1.0 \mathrm{~K} / \mathrm{min}$., pores were found at the fracture surface inside of sintered parts, which might be caused due to rapid temperature increases. During decreasing, abrupt increases in the temperature caused fast evaporation of thermoplastic binder inside specimen, thereby ceramic powder which was not sintered was pushed out to outside, forming pores inside, which ultimately generated phenomenon like bloating on surface of the specimen. ${ }^{10)}$

While, if heating rate till debinding temperature was 0.5 $\mathrm{K} / \mathrm{min}$, though pore was not found on the fracture surface of the specimen, a few bloating on the surface was found. Whilst, when heating rate was at $0.2 \mathrm{~K} / \mathrm{min}$, bloating of outer shape or pores in the inner fracture surface were not found at all. It might be because heating rate was sufficiently lowered so that thermoplastic binder inside the specimen could be evaporated sequentially. While binder on the surface was evaporated first, path was formed, and binders remained inside were evaporated, so that defects such as inner pore or bloating could be prevented. The effect of heating rate till debinding temperature on the flexural strength of the specimen after sintering is presented in Fig. 3. As heating rate became slower, flexural strength was increased, but flexural strength was not changed at heating rate lower than $0.5 \mathrm{~K} / \mathrm{min}$. As has mentioned before, flexural strength might have been decreased due to defects such as bloating or inner pores by rapid heating rate. As a result, it was confirmed that in the debinding process of the injected parts which use thermoplastic binder based on the paraffin wax, temperature was increased with speed at lower than $0.5 \mathrm{~K} / \mathrm{min}$, thus defect in the injected part could be restricted internally and externally.

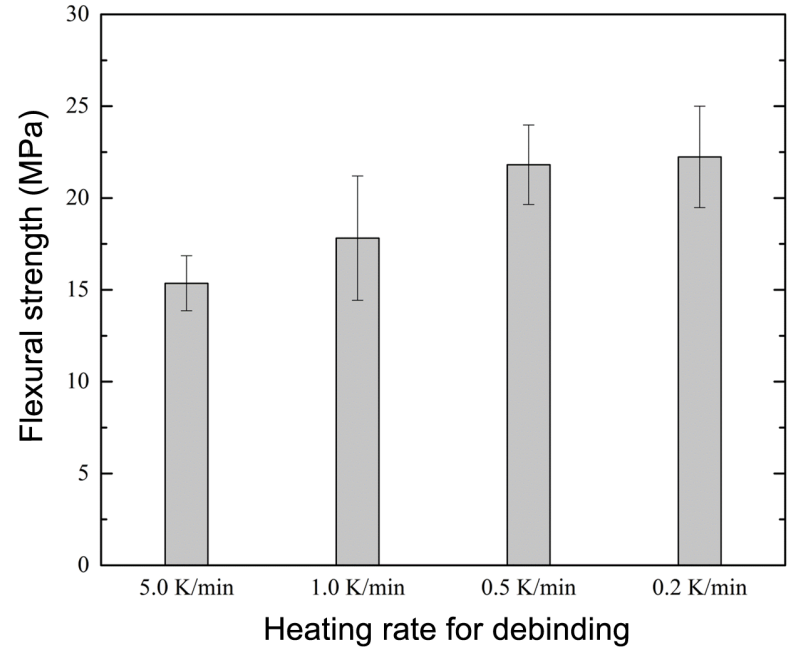

Fig. 3. Flexural strength of specimens with various heating rate for debinding.

\subsection{Mechanical Properties of Ceramic Core with various sintering condition}

Generally, fused silica having amorphous structure is known to be sintered in a temperature range of 1000 $1300^{\circ} \mathrm{C}^{12)}$ Therefore, heat treatment for ceramic core was proceeded in a range from $1150^{\circ} \mathrm{C}$ until $1400^{\circ} \mathrm{C}$ to sinter fused silica which is a primary material for the ceramic core. Fig. 4 (a) is a graph displaying flexural strength and shrinkage rate of the specimen which was heat treated at $1150-1400^{\circ} \mathrm{C}$ after increasing temperature for $12 \mathrm{~h}$ with speed at $0.2 \mathrm{~K} / \mathrm{min}$ until $300^{\circ} \mathrm{C}$ for debinding. Flexural strength of the ceramic core showed the highest value $(22 \mathrm{MPa})$ when it was sintered at $1200^{\circ} \mathrm{C}$ for $12 \mathrm{~h}$. Linear shrinkage rate at this time was around $2.5 \%$.

While, when ceramic core was treated at higher than $1300^{\circ} \mathrm{C}$, flexural strength was rather decreased, and shrinkage rate was increased. This might be because volume contraction by phase transition of cristobalite which is a crystalline phase of fused silica and consequent microcrack. ${ }^{6,13,14)}$ Fused silica which is a primary material of ceramic core is crystallized to $\beta$-cristobalite having cubic structure at higher than $1300^{\circ} \mathrm{C}$. $\beta$-cristobalite thus produced goes through phase-transformation to $\alpha$-cristobalite having a tetragonal structure during cooling (in a temperature range of $200-300^{\circ} \mathrm{C}$ ) after heat treatment. At this time, volume contraction is occurred at $5 \%$ due to difference in the dimensions of unit cell, ${ }^{15)}$ and microcracks are produced by the stress induced by volume contraction. ${ }^{16)}$ As a result, shrinkage of ceramic core becomes increased and flexural strength becomes decreased., ${ }^{2,5,17}$ Therefore, when ceramic core was heat-treated under high temperature at higher than $1300^{\circ} \mathrm{C}$, large amount of cristobalite was formed, thereby shrinkage rate was increased and fracture strength was lowered.

Formation of cristobalite by increasing the sintering temperature could be confirmed by X-ray diffraction analysis 


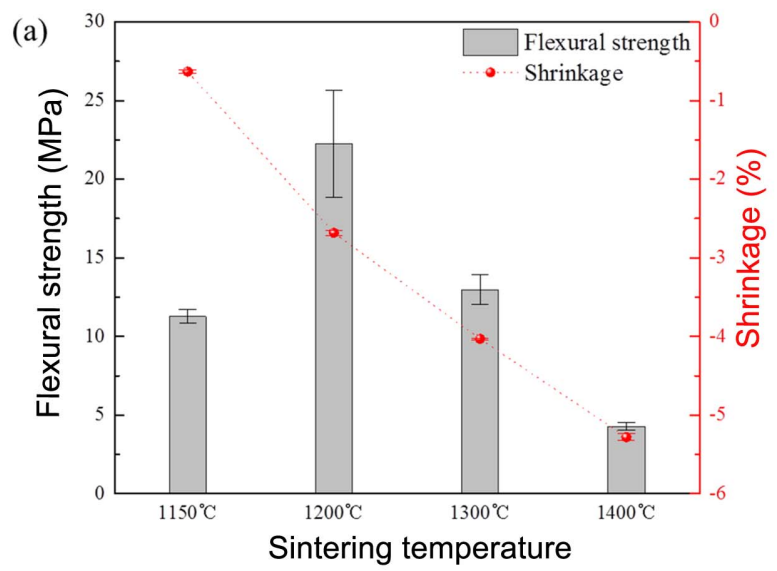

(b)

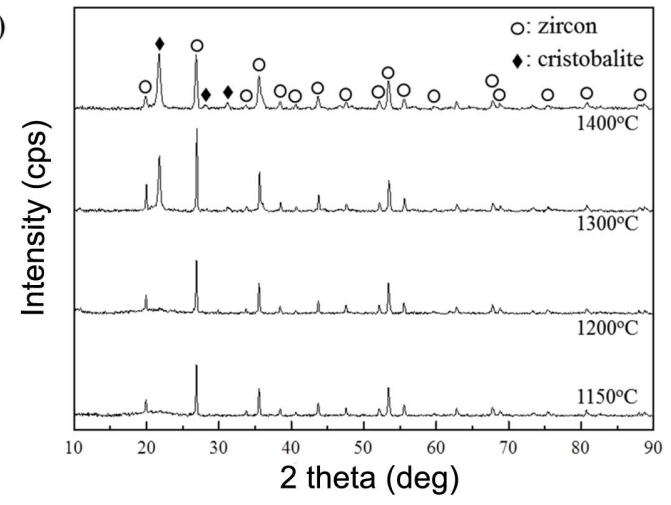

Fig. 4. Flexural strength, shrinkage and XRD patterns of specimens with various sintering temperature.

results. (Fig. 4 (b)) In case of ceramic core which was heattreated at $1150^{\circ} \mathrm{C}$ and $1200^{\circ} \mathrm{C}$, cristobalite phase was not appeared, while the ceramic core sintered at higher than $1300^{\circ} \mathrm{C}$, had cristobalite phases. Zircon peak $\left(26.86^{\circ}\right.$, (200) plane, JCPDS no.6-266), and cristobalite peak $\left(21.68^{\circ},(110)\right.$ plane, JCPDS no.39-1425) in the X-ray diffraction graph were compared in order to directly assess crystallization degree of fused silica to cristobalite. (Table 3) All the specimens have same content of zircon, and zircon is thermally degraded into silica $\left(\mathrm{SiO}_{2}\right)$ and zirconia $\left(\mathrm{ZrO}_{2}\right)$ at higher than $1600^{\circ} \mathrm{C}$, therefore zircon contents would be same after sintering. Therefore, it is possible to assume a relative crystallized amount of cristobalite with above method. ${ }^{13,14)}$ Comparison of zircon peak and cristobalite peak showed that crystallized cristobalite contents were abruptly increased in the ceramic core which was treated at $1300^{\circ} \mathrm{C}$, and as sinter-

Table 3. Cristobalite to Zircon Peak Ratio of Ceramic Cores Sintered at Various Temperatures

\begin{tabular}{cc}
\hline $\begin{array}{c}\text { Sintering conditions } \\
\text { [Temp.-Time] }\end{array}$ & $\begin{array}{c}\text { Cristobalite/zircon } \\
\text { peak ratio }\end{array}$ \\
\hline $1150^{\circ} \mathrm{C}-12 \mathrm{~h}$ & 0.0952 \\
$1200^{\circ} \mathrm{C}-12 \mathrm{~h}$ & 0.1271 \\
$1300^{\circ} \mathrm{C}-12 \mathrm{~h}$ & 0.6686 \\
$1400^{\circ} \mathrm{C}-12 \mathrm{~h}$ & 1.0319 \\
\hline
\end{tabular}

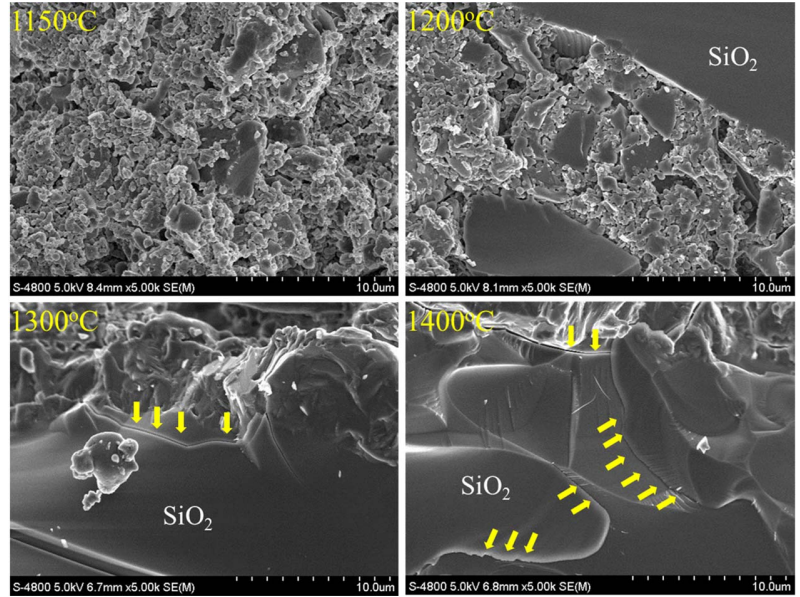

Fig. 5. Microstructures of specimens with various sintering temperatures.

ing temperature become increased to $1400^{\circ} \mathrm{C}$, crystallized cristobalite contents might be further increased.

Examination of microstructure of ceramic core revealed that microcrack was generated due to phase transformation of cristobalite which was formed at high sintering temperature that caused flexural strength decreased. (Fig. 5) Powders did not look sintered as in the microstructure of ceramic core sintered at $1150^{\circ} \mathrm{C}$, while ceramic core treated at lower than $1200^{\circ} \mathrm{C}$ did not show microcrack in the silica zone. However, microcrack was found in the silica particle when the ceramic core was treated at higher than $1300^{\circ} \mathrm{C}$ (at the arrow area), and were mostly formed on the surface of the silica particle. This was because crystallization of cristobalite of fused silica started from the surface. ${ }^{6,17,18)}$ Consequently, temperature $1150^{\circ} \mathrm{C}$ would not be sufficient to sinter a fused silica, and high sintering temperature higher than $1300^{\circ} \mathrm{C}$ would rather deteriorate physical properties of fused silica by promoting crystallization.

Figure 6 shows flexural strength, shrinkage, and X-ray diffraction of the ceramic core sintered at $1200^{\circ} \mathrm{C}$ for different dwelling time. Flexural strength and shrinkage by increases of sintering time showed an almost same trend with physical properties changes by sintering temperature. In case of the ceramic core that was sintered for $6 \mathrm{~h}$, a low flexural strength lower than $10 \mathrm{MPa}$ was found. When ceramic core was heat-treated for $12 \mathrm{~h}$, the highest flexural strength could be achieved. While, if ceramic core was sintered for longer than $24 \mathrm{~h}$, flexural strength was decreased as sintering time was increased, same as it was sintered at higher than $1300^{\circ} \mathrm{C}$, and shrinkage was increased. X-ray diffraction analysis showed that when sintering time was extended for longer than $24 \mathrm{~h}$, fused silica was crystallized same as in the case of sintering temperature increases, and cristobalite peak was increased abruptly. Therefore, a longer sintering temperature at $1200^{\circ} \mathrm{C}$ would promote crystallization of fused silica inside the ceramic core leading to degradation in flexural strength and shrinkage. 
(a)

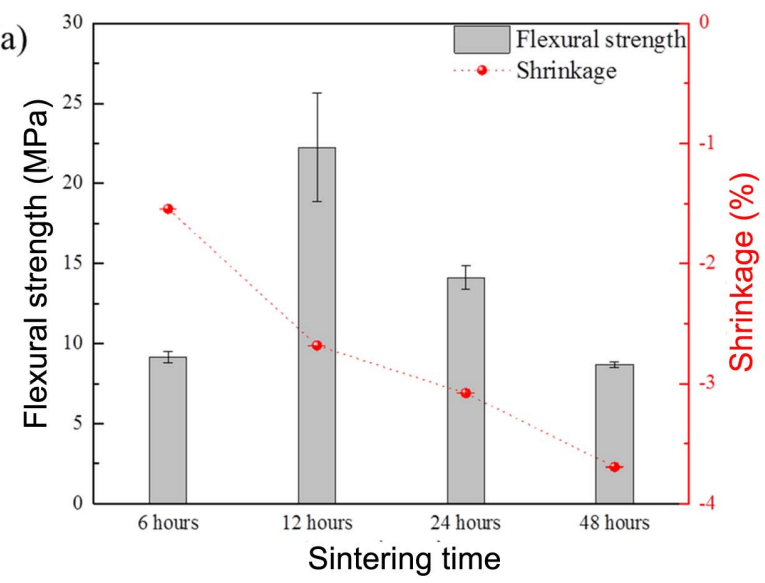

(b)

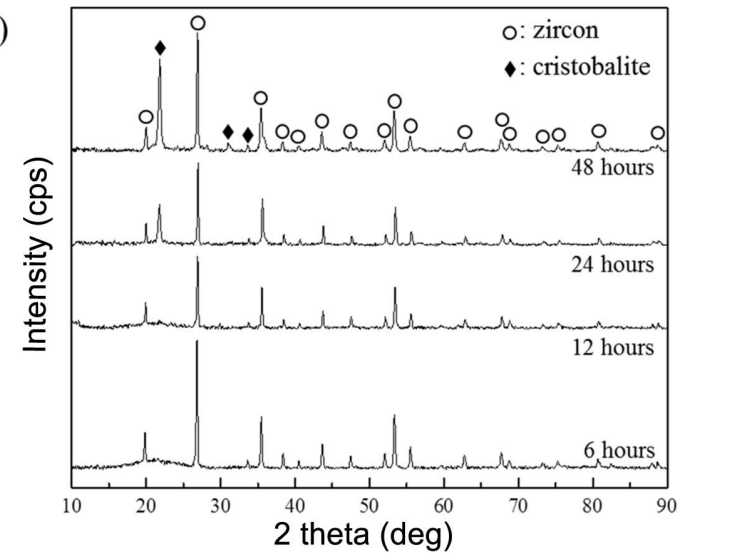

Fig. 6. Flexural strength, shrinkage and XRD patterns of specimens with various dwelling time for sintering.

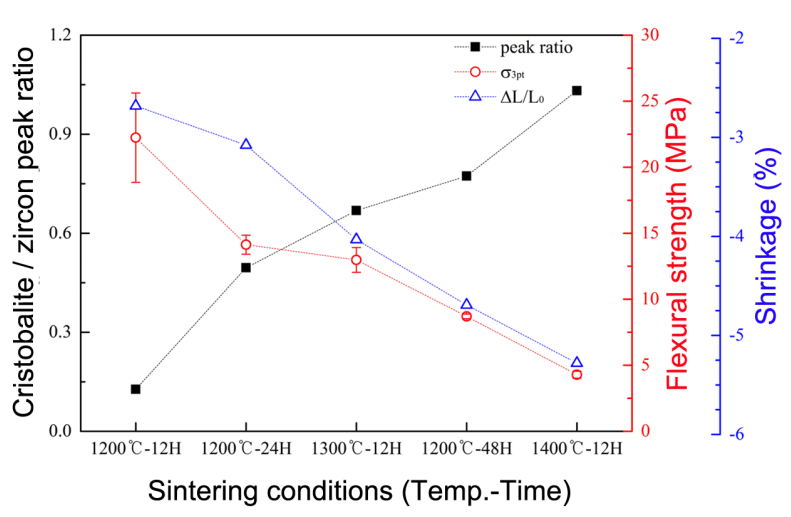

Fig. 7. Correlation of cristobalite/zircon peak ratio with flexural strength/shrinkage of ceramic cores.

Flexural strength and changes in shrinkage of the ceramic core by relative cristobalite contents in the specimens sintered under the different condition are presented in Fig. 7 in order to investigate effect of cristobalite contents on the physical properties of the ceramic core. Since it was found that heat treatment lower than $1200^{\circ} \mathrm{C}$ would not be sufficient for sintering and crystallization of fused silica as proved in the previous experiment, only flexural strength and changes of shrinkage by cristobalite contents of ceramic
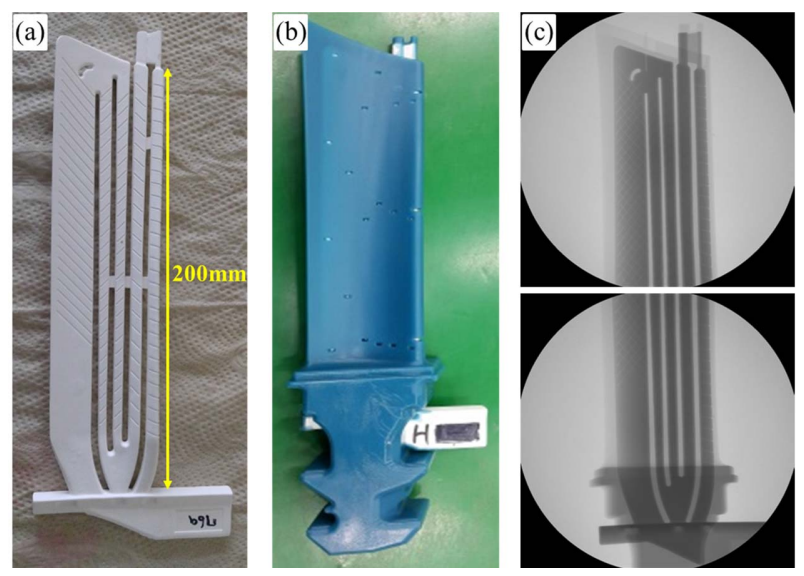

Fig. 8. Images of (a) sintered ceramic core, (b) wax patterned ceramic core, and (c) X-ray analysis result after wax patterning.

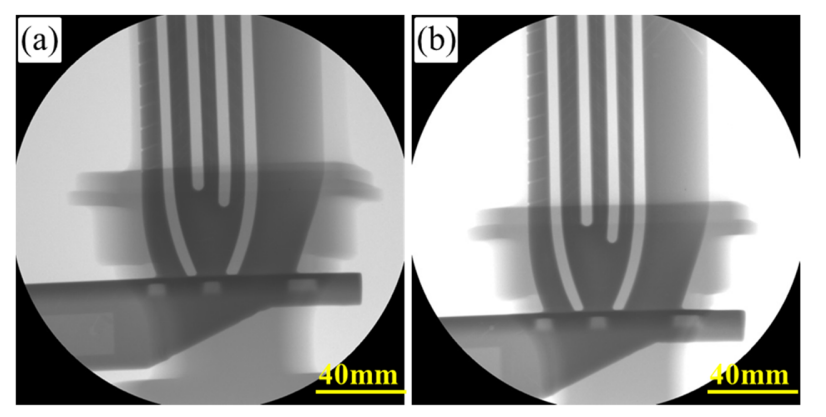

Fig. 9. X-ray images of wax patterned ceramic core; sintered at (a) $1150^{\circ} \mathrm{C}$, and (b) $1200^{\circ} \mathrm{C}$ for $12 \mathrm{~h}$.

core treated at higher than $1200^{\circ} \mathrm{C}$ were compared. In spite of sintered at different temperature zone and heat treatment, as cristobalite contents were increased, flexural strength of the ceramic core was decreased, but shrinkage was increased. This means that as much as fused silica is crystallized, fracture strength of the ceramic core is decreased and shrinkage is increased. Ultimately, crystallization of fused silica needs to be restricted in order to provide adequate fracture strength and low shrinkage to ceramic core.

\subsection{Wax Patterning and Shell Molding for Invest- ment Casting}

Ceramic core goes through wax patterning and shell molding processes for investment casting of superalloys. The wax pattern (Fig. 8(b)) was produced using the obtained ceramic core (Fig. 8(a)) which was heat-treated after ceramic injection molding, and the X-ray inspection was carried out as in Fig. 8(c). The specimen sintered at $1300^{\circ} \mathrm{C}$ and $1400^{\circ} \mathrm{C}$ might have cracks inside and the resultant strength reduction. Therefore, the ceramic core was heat-treated at $1150^{\circ} \mathrm{C}$ and $1200^{\circ} \mathrm{C}$ for $12 \mathrm{~h}$. X-ray inspection of specimens sintered at $1150^{\circ} \mathrm{C}$ and $1200^{\circ} \mathrm{C}$ did not have defects such as crack even after wax patterning (Fig. 9).

Shell molding process was performed using the wax-pat- 

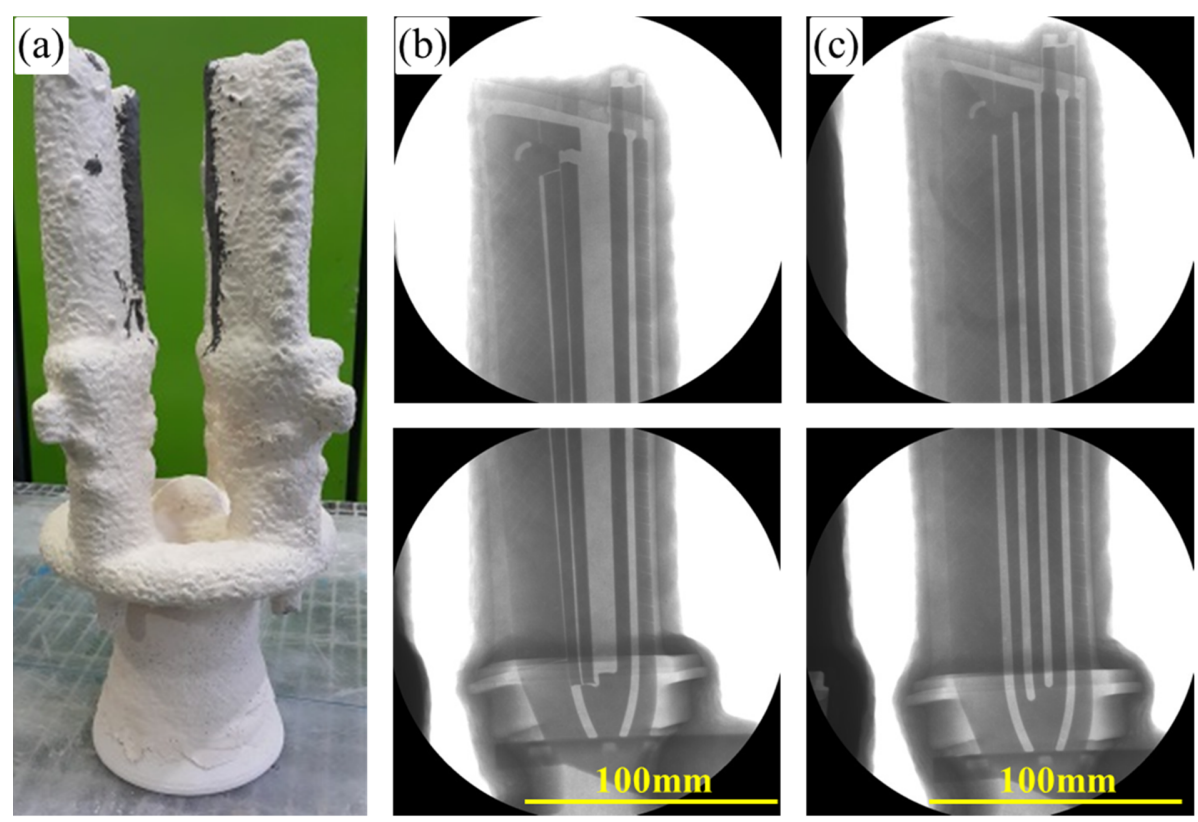

Fig. 10. (a) Image of sintered shell mold, (b) X-ray images of shell mold include ceramic core sintered at $1150^{\circ} \mathrm{C}$ for $12 \mathrm{~h}$, and (c) X-ray images of shell mold include ceramic core sintered at $1200^{\circ} \mathrm{C}$ for $12 \mathrm{~h}$.

terned ceramic core showing no defects, which was heattreated at $1150^{\circ} \mathrm{C}$ and $1200^{\circ} \mathrm{C}$. High temperature sintering of shell mold was carried out (Fig. 10 (a)). X-ray inspection of shell mold after sintering showed that the ceramic core produced under the sintering temperature at $1150^{\circ} \mathrm{C}$ was fractured inside. (Fig. 10 (b)) While, there was no defects such as fracture or crack in the ceramic core even after sintering the shell mold. (Fig. 10 (c)) Since strength was not fully developed in the ceramic core treated at $1150^{\circ} \mathrm{C}$, it would have been fractured during sintering the shell mold. While, ceramic core treated at $1200^{\circ} \mathrm{C}$ for $12 \mathrm{~h}$, which had a sufficient strength, did not generate defect or fracture even after wax patterning and shell molding.

\section{Conclusions}

1) When heating rate was higher than $0.5 \mathrm{~K} / \mathrm{min}$ until debinding temperature, a bloating of thermoplastic binder inside the injection molded ceramic core was occurred due to abrupt evaporation. Therefore, bloating of surface in the sintered specimen could be controlled by applying slow heating rate at $0.2 \mathrm{~K} / \mathrm{min}$.

2) Ceramic core showed a low flexural strength when sintered at $1150^{\circ} \mathrm{C}$, because this temperature was not sufficient enough to sinter fused silica which is a matrix material in the ceramic core. Further, when sintering temperature was higher than $1300^{\circ} \mathrm{C}$, formation of the cristobalite which caused volume contraction and microcrack was enhanced, thus flexural strength of ceramic core was decreased and shrinkage was increased.

3) Flexural strength and shrinkage by increasing dwelling time at $1200^{\circ} \mathrm{C}$ showed the similar trend with mechanical properties of ceramic core by increased sintering temperature. It was because crystallization of fused silica was closely related with mechanical properties of ceramic core. Further, as relative content of the cristobalite was increased, flexural strength was decreased and shrinkage was increased.

4) Ceramic core having a flexural strength higher than 10 $\mathrm{MPa}$ could withstand injection molding pressure during wax patterning.

5) The ceramic core sintered at $1150^{\circ} \mathrm{C}$ was fractured due to the low flexural strength during shell mold sintering. Whilst, the ceramic core sintered at $1200^{\circ} \mathrm{C}$ had a sufficient flexural strength, and was not fractured even during wax patterning and shell mold sintering.

\section{Acknowledgements}

This work was supported by the Power Generation and Electricity Delivery Core Technology Program of the Korea Institute of Energy Technology Evaluation and Planning (KETEP), which was granted financial resources from the Ministry of Trade, Industry and Energy, Republic of Korea (2014101010187B).

\section{REFERENCES}

1. J. W. Kim, D. H. Kim, I. S. Kim, Y. S. Yoo, J. C. Kim, and C. Y. Jo, "Study on the Fabrication of Ceramic Core Using a Gel-Casting Process in Aqueous Medium(I) : Gelation Behavior of Polydispered Ceramic Slip (in Korean)," Korean J. Mater. Res., 11 [2] 137-45 (2001).

2. I. Huseby, M. Borom, and C. Greskovich, "High Tempera- 
ture Characterization of Silica-Base Cores for Superalloys," Am. Ceram. Soc. Bull., 58 448-52 (1979).

3. P. Wilson, S. Blackburn, R. Greenwood, B. Prajapti, and K. Smalley, "The Role of Zircon Particle Size Distribution, Surface Area and Contamination on The Properties of Silica-Zircon Ceramic Materials,” J. Eur. Ceram. Soc., 31 [9] 1849-55 (2011).

4. A. Wereszczak, K. Breder, M. Ferber, T. Kirkland, E. Payzant, C. Rawn, E. Krug, C. Larocco, R. Pietras, and M. Karakus, "Dimensional Changes and Creep of Silica Core Ceramics used in Investment Casting of Superalloys," $J$. Mater. Sci., 37 [19] 4235-45 (2002).

5. C. H. Chao and H. Y. Lu, "Optimal Composition of ZirconFused Silica Ceramic Cores for Casting Superalloys," J. Am. Ceram. Soc., 85 [4] 773-79 (2002).

6. C. J. Bae and J. W. Halloran, "Integrally Cored Ceramic Mold Fabricated by Ceramic Stereolithography," Int. J. Appl. Ceram. Tec., 8 [6] 1255-62 (2011).

7. L. Y. Wang and M. H. Hon, "The Effects of Zircon Addition on The Crystallization of Fused Silica. A Kinetic Study," J. Ceram. Soc. Jpn., 102 [6] 517-21 (1994).

8. J. W. Kim, D. H. Kim, I. S. Kim, Y. S. Yoo, B. K. Choi, E. H. Kim, and C. Y. Jo, "Study on The Fabrication of Ceramic Core using a Gel-casting Process in Aqueous Medium(II) : Physical Properties of Sintered Ceramic Core Body (in Korean)," Korean J. Mater. Res., 11 [6] 465-71 (2001).

9. M. Gromada, A. Swieca, M. Kostechki, A. Olszyna, and R. Cygan "Ceramic Cores for Turbine Blades via Injection Moulding," J. Mater. Process. Tech, 220 107-12 (2015).

10. B. C. Mutsuddy and R. G. Ford, Ceramic Injection Molding; pp. 245-90, Chapman \& Hall, London, 1994.

11. ASTM C1161-13, "Standard Test Method for Flexural Strength of Advanced Ceramics at Ambient Temperature," ASTM International, West Conshohocken, PA, 2013.

12. C. J. Bae, "Integrally Cored Ceramic Investment Casting Mold Fabricated by Ceramic Stereolithography," pp. 174210, in Ph. D. Thesis, University of Michigan, Ann Arbor, 2008.

13. A. Kazemi, M. A. Faghihi-Sani, M. Nayyeri, M. Mohammadi, and M. Hajfathalian, "Effect of Zircon Content on Chemical and Mechanical Behavior of Silica-based Ceramic Cores," Ceram. Int., 40 [1] 1093-98 (2014).

14. A. Kazemi, M. A. Faghihi-Sani, and H.R. Alizadeh, "Investigation on Cristobalite Crystallization in Silica-based Ceramic Cores for Investment Casting," J. Eur. Ceram. Soc., 33 [15] 3397-402 (2013).

15. A. Leadbetter and A. Wright, "The $\alpha-\beta$ Transition in The Cristobalite Phases of $\mathrm{SiO}_{2}$ and $\mathrm{AIPO}_{4}$ I. X-ray Studies," Philos. Mag., 33 [1] 105-12 (1976).

16. C. H. Chao and H. Y. Lu, "Stress-Induced $\beta \rightarrow a-C r i s t o b a l i t e$ Phase Transformation in $\left(\mathrm{Na}_{2} \mathrm{O}+\mathrm{Al}_{2} \mathrm{O}_{3}\right)$-Codoped Silica," Mat. Sci. Eng. A, 328 [1] 267-76 (2002)

17. R. C. Breneman and J. W. Halloran, "Effect of Cristobalite on the Strength of Sintered Fused Silica Above and Below the Cristobalite Transformation," J. Am. Ceram. Soc., 98 [5] 1611-17 (2015).

18. N. Lequeux, N. Richard, and P. Boch, "Shrinkage Reduction in Silica-Based Refractory Cores Infiltrated with Boehmite," J. Am. Ceram. Soc., 78 [11] 2961-66 (1995). 